\title{
Energy Budgeting and Sensitivity Analysis of Rice (Oryza sativa) - Wheat (Triticum aestivum) Cropping System in Indogangentic Plains of India
}

\author{
V. Paramesh ${ }^{1}$, N. Ravisankar ${ }^{2}$, Bappa $\operatorname{Das}^{1}$, K. Viswanatha $\operatorname{Reddy}^{1}$ and \\ Narendra Pratap Singh ${ }^{1}$
}

\author{
${ }^{1}$ ICAR- Central Coastal Agricultural Research Institute, Old Goa, Goa -403402, India \\ ${ }^{2}$ ICAR- Indian Institute of farming system research, Modipuram, Meerut, Uttar Pradesh, India \\ *Corresponding author
}

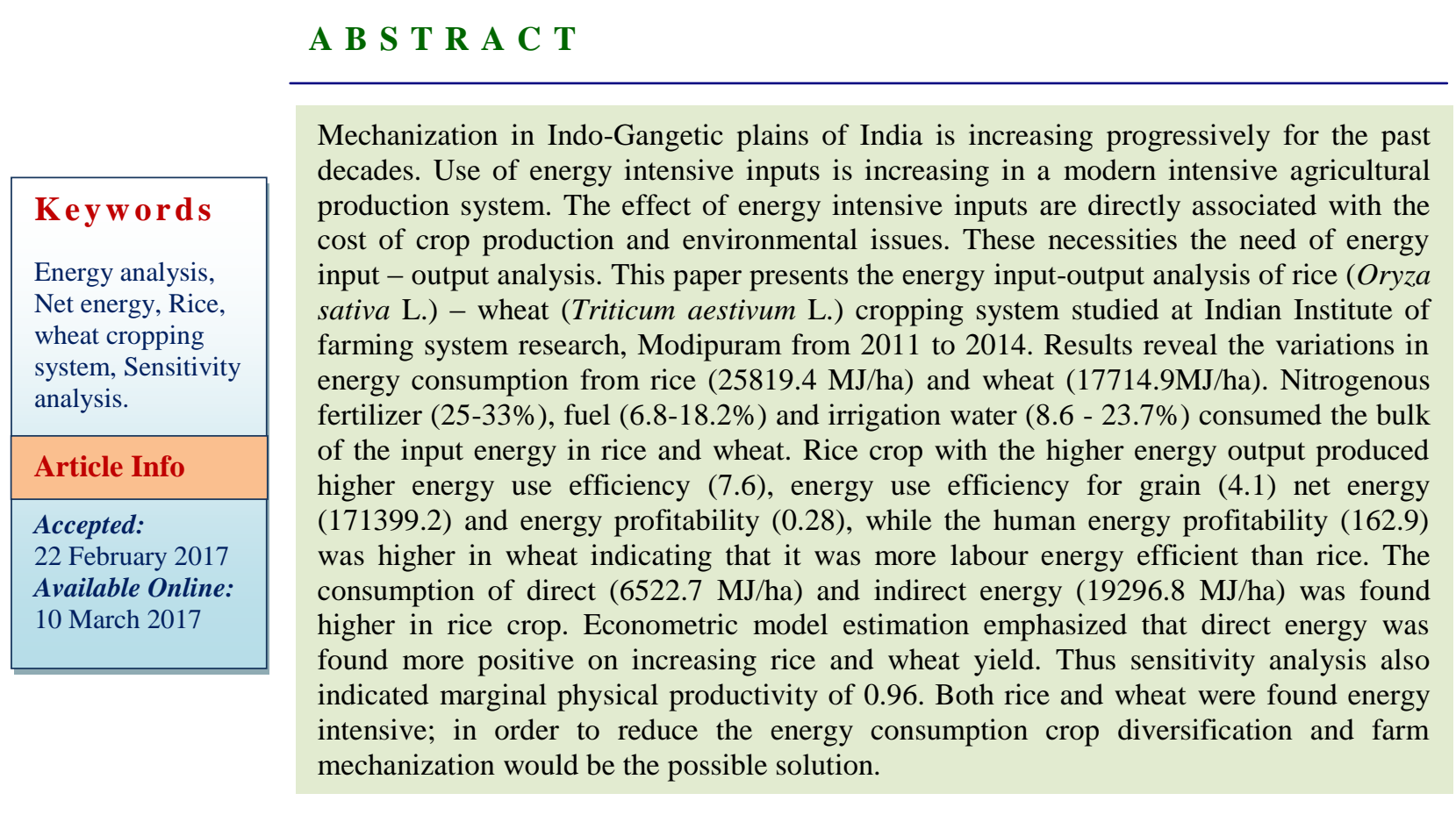

\section{Introduction}

Rice - wheat cropping system is one of the most important cropping systems of the country which contributes about 32 per cent to the national food basket (Dhillon et al., 2010). Both rice and wheat is the most important staple food crop of millions of people in South East Asia, particularly in India. Therefore, their sustained high productivity is inevitable for achieving national food security (Chaudhary et al., 2006).
Presently, the productivity of this cropping system is stagnated and became threatening to national food security (Gupta and Seth, 2007). Rice-wheat cropping system requires a huge amount of input energy for growing the seedlings, puddling, transplanting, irrigation, fertilizer and weed management.

Among different indicators of crop performance, the energy analysis is one of the 
most important. The net output energy of a cropping system can be assessed for planning of sustainable cropping systems. Unlike soil fertility, crop yield is inversely related to energy use efficiency, energy productivity, and energy intensiveness (Tuti et al., 2012). Large scale implementation of low input agricultural practices and timely problem solving in the farm will contribute to overcome the energy crisis and which will be a considerable input in ensuring the national food security. Hence, the efficient use of energy is of main concern to maximize the system productivity and to achieve sustainability. Energy efficient cropping system will minimize atmospheric pollution by reducing the use of external inputs and promote farming as an economically sustainable production option to the future (Erdal et al., 2007). However, with scarce and contamination of natural resources, the farm productivity is stagnating. Increasing the energy use efficiency is the only possible solution to lower the environmental hazard due to modern agricultural practices (Esengun et al., 2007).

In developing countries like India, farm mechanization is a prime necessity to reduce human drudgery and to increase the output per unit area. This can only be achieved by shifting from traditional energy source i.e. human labour with substantial investments in farm machinery, water management practices, chemicals (fertilizers and pesticides), weed management practices, resource conservation practices, etc. (Amare and Endalew, 2016). These energy inputs and methods need to be evaluated to know their effectiveness and efficiency for future conservation of scarce natural resources. In this background, the energy analysis is done to quantify the energy investment in every step of crop production and for identification of economical and effective practices. The study was undertaken to estimate and compare the energy requirements of the production in rice and wheat.

\section{Materials and Methods}

The field experiments were carried out (201112 to 2013-14) to estimate the energy of inputs, outputs, energy use efficiency and net energy return of the rice-wheat cropping system at the research farm of the ICARIndian Institute of the Farming System Research, Modipuram, Meerut (Uttar Pradesh). For energy budgeting of this cropping system, three years average input and output data were considered. For rice in Kharif, all plots were ploughed twice and tilled once with a power tiller. Thereafter, water was flooded to about $10 \mathrm{~cm}$ depth for $24 \mathrm{~h}$ for puddling.

The field was prepared for the wheat crop with two harrowing, planking and leveling. The details of all inputs used in cropping system through various activities are given in table 2. The crop was raised on natural soil fertility and the nutritional requirements of the crop were met through application of mineral fertilizers and farmyard manure (FYM). The recommended dose of fertilizers and chemicals were applied as per the need of the crop. Pressure due to insect pests and diseases was generally low for most of the seasons during the experimental years. Once the crop was grown, harvested yields of main and by-products of each crop were measured.

\section{Methods of energy calculation}

An energy flux of rice-wheat cropping system was estimated using crop management and biomass production records. To study energy inputs and outputs of cropping system, a complete inventory of all the crop inputs (fertilizers, seeds, plant protection chemicals, fuels, human labor and machinery power) and outputs of both main and by-products was 
prepared. The energy value of cropping system was determined based on energy inputs and energy production for the individual crops in the system. Inputs and outputs were converted from physical to energy unit measures through conversion coefficients (Table 1).

The following equations were used to calculate different energy indices for rice wheat cropping system.

Energy use efficiency=(Energy input (MI ha)) (Energy output (MI ha)) Net Energy=(Energy input (MIha))-(Energy output (MI ha)) Energy profitability $=($ Net energy $(\mathrm{MI} / \mathrm{ha}))($ (Energy input $(\mathrm{MIJ} / \mathrm{ha}))$ Direct energy $=$ Labour $*$ Fuel $\oplus$ Electricity Indirect energy $=$ Seed + Feed + Fettilizers + Chemicals + Machineines finigation Renewable energy $=$ Labor $₫$ Organic Fertilizers

Non-renewable energy $=$ Fuel + Electricity + Seed + Feed + Synthetic Fertilizers + Chemicals + Machineries

Human energy profitability = Output energy (MI ha) / Labour energy (MI/ha) Energy productivity = Crop economic yield (kg ha) / Energy input (MI ha)

\section{Production functions}

The impact of direct, indirect, renewable and non-renewable energy on rice and wheat yield were evaluated by using Cobb-Douglas production function in following forms

$$
\begin{aligned}
& \ln Y_{i}=\beta_{0}+\beta_{1} \ln (D E)+\beta_{2} \ln (I D E)+\varepsilon_{i} \\
& \ldots \ldots \ldots \ldots \ldots . . .11) \\
& \ln Y_{i}=\gamma_{0}+\gamma_{1} \ln (R E)+\gamma_{2} \ln (N R E)+\varepsilon_{i}
\end{aligned}
$$

where, $Y i$ denotes the yield of the ith farmer, $D E, I D E, R E$ and $N R E$ are direct, indirect, renewable and non-renewable energy which are used for rice and wheat production respectively, $\beta i$ and $\gamma \mathrm{i}$ are the coefficients of variables, $\beta_{0}$ and $\gamma_{0}$ are the constants and $\varepsilon i$ is the error term. For computation of above equation, data were used years wise.
The marginal physical productivity (MPP) technique was used to know the sensitivity of a different energy sources on productivity of the rice wheat cropping system based on the response coefficients of the inputs. The MPP of the various energy sources was computed using the $\beta_{\mathrm{j}}$ of the various energy inputs as under

$\mathrm{MPP}_{\mathrm{xj}}=\frac{\mathrm{GM}(\mathrm{Y})}{\mathrm{GM}(\mathrm{x})_{\mathrm{j}}} \times \beta$

where, $\mathrm{MPP}_{\mathrm{xj}} \mathrm{MPP}$ of $\mathrm{jth}$ input, $\beta_{\mathrm{j}}$ regression coefficient of jth input, GM (Y) geometric mean of productivity, GM $\left(\mathrm{X}_{\mathrm{j}}\right)$ geometric mean of jth input on farm per hectare basis.

\section{Return to scale}

The return to scale is indicated by the sum of the coefficients $\left(\Sigma \beta_{\mathrm{j}}\right)$ derived from regression equations in Cobb-Douglas production function. If the sum of the coefficients is less than or equal to or greater than unity, then the returns to scale will be decreasing or constant, or increasing, respectively.

\section{Results and Discussion}

\section{Crop yields and resource consumption}

Resource consumption, outputs and byproducts produced from rice - wheat cropping system is presented in table 2 . The mean data of three years revealed that among different inputs the use of farm yard manure (7500 $\mathrm{kg} / \mathrm{ha}$ in rice and $5000 \mathrm{~kg} / \mathrm{ha}$ in wheat) was found higher followed by irrigation input in both the crops. The labor requirement (802.4 man $\mathrm{hr} / \mathrm{ha}$ ) for rice was more compared to wheat (414.6 man $\mathrm{hr} / \mathrm{ha}$ ) due to manual transplanting, frequent weeding in rice and maintenance needs.

Wheat utilized notable amount of fossil fuel $(67.2 \mathrm{l} / \mathrm{ha})$ because of tedious field preparation after rice harvest and for drill sowing of wheat seeds. Because of manual 
weeding and lesser incidence of insect pest, the use of insecticide/weedicide was nil in wheat while it was necessary due to higher weed and pest infestation in rice $(12.2 \mathrm{~kg} / \mathrm{ha})$. As both rice and wheat are exhaustive in nature application of synthetic fertilizer was found higher. Among different nutrients, N application rate $(106.4$ and $97.6 \mathrm{~kg} / \mathrm{ha}$ in rice and wheat, respectively) was generally higher to $\mathrm{P}(68.5$ and $96.5 \mathrm{~kg} / \mathrm{ha}$ in rice and wheat, respectively) and $K(60.2 \mathrm{~kg} / \mathrm{ha}$ in rice and wheat). The use of irrigation was found higher in rice $\left(6000 \mathrm{~m}^{3} / \mathrm{ha}\right)$ compare to wheat $\left(1500 \mathrm{~m}^{3} / \mathrm{ha}\right)$. The water usage in wheat was found lower because the crop was irrigated only at critical stages of crop growth while in rice, $2 \mathrm{~cm}$ of water level was maintained up to dough stage. The yields of main and byproduct of rice $(7179$ and $7335 \mathrm{~kg} / \mathrm{ha})$ were found higher than wheat (4710 and 5048 $\mathrm{kg} / \mathrm{ha}$ ).

\section{Energy input-output analysis}

The energy consumption of rice and wheat are presented in table 3 . The total energy input was found higher in rice $(25819.4 \mathrm{MJ} / \mathrm{ha})$ compare to wheat $(17714.9 \mathrm{MJ} / \mathrm{ha})$. It was mainly due to higher energy input in terms of $\mathrm{N}$ fertilizers, manure management (FYM application) and frequent irrigation in rice (Table 2) compare to wheat. Bockari-Gevao et al., (2005) reported energy input of 12.4 $\mathrm{GJ} / \mathrm{ha}$ for rice in Malaysia, which mostly depended on chemical fertilizer $(7.7 \mathrm{GJ} / \mathrm{ha})$. The total energy output was also found higher in rice $(197218.7 \mathrm{MJ} / \mathrm{ha})$ due to higher main and by-product yield of rice compare to wheat (Table 2).

\section{Energy indices}

Energy indices are presented in table 4 . The energy use efficiency, energy profitability, and energy productivity of rice (7.6, 6.6 and $0.28 \mathrm{~kg} / \mathrm{MJ})$ and wheat $(7.5,6.5$ and 0.27 $\mathrm{kg} / \mathrm{MJ})$ were found almost similar during the study period. This was mainly due to the large amount of available residues with a significant energy potential in addition to its main crop yield in both the crops. Energy use efficiency of main product $\left(\mathrm{EUE}_{\mathrm{M}}\right)$ for rice (4.9) is higher than wheat due to higher average grain yield of rice than wheat (Table 2). Earlier scientists reported different $\mathrm{EUE}_{\mathrm{M}}$ values for different crops like 7.2 for wheat (Singh et al., 1997), 8.4 for maize (Hetz, 1992) and 0.8 for stake-tomato (Esengun et al., 2006). Bockari-Gevao et al., (2005) reported $\mathrm{EUE}_{\mathrm{M}}$ for rice without irrigation was 8.86 for Malaysia. Rutger and Grant (1980) reported an $\mathrm{EUE}_{\mathrm{M}}$ value of 1.03-1.76 for USA and 3.36-3.41 for Philippines for irrigated, where labor energy was not included during the calculation. Whereas in this study, $\mathrm{EUE}_{\mathrm{M}}$ was found higher since intensive labour usage was included. The human energy profitability was found higher in wheat (162.9) compare to rice (125.4) due to higher energy output per unit of labour energy usage.

\section{Percentage of energy consumption}

Percent of energy usage from different sources are presented in table 5 (Fig. 1). It shows that indirect energy input in rice and wheat were around $75 \%$ of its total energy input. Rice consumes more indirect energy, out of which $25 \%$ from $\mathrm{N}$ fertilizer only followed by irrigation $(23.7 \%)$. In wheat, the indirect energy input from $\mathrm{N}$ fertilizer $(33.7 \%)$ was found higher followed by $\mathrm{K}$ fertilizer (13.3\%). Among direct energy sources, Wheat consumed more direct energy, out of which $18.2 \%$ from fossil fuel. The usage of nonrenewable energy (Fig. 1) was found higher in both the crops $(56.6 \%$ and $73.5 \%$ in rice and wheat, respectively). This was mainly due to higher reliance on synthetic fertilizers, agrochemicals and frequent irrigation in both the crops. 
Table.1 Energy equivalents of inputs and outputs in agricultural production

\begin{tabular}{|c|c|c|c|}
\hline Input & Unit & MJ/Unit & Reference \\
\hline Labor & Man hr & 1.96 & Singh and Mittal (1992) \\
\hline Fossil fuel (Diesel) & lit. & 47.87 & Cervinka (1980) \\
\hline Electricity & $\mathrm{kWh}$ & 3.6 & Ozkana et al., (2004) \\
\hline Nitrogen $(\mathrm{N})$ & $\mathrm{kg}$ & 60.6 & Singh and Mittal (1992) \\
\hline Phosphorus $\left(\mathrm{P}_{2} \mathrm{O}_{5}\right)$ & $\mathrm{kg}$ & 11.1 & Singh and Mittal (1992) \\
\hline Potassium $\left(\mathrm{K}_{2} \mathrm{O}\right)$ & $\mathrm{kg}$ & 6.7 & Singh and Mittal (1992) \\
\hline Farm Yard Manure & $\mathrm{kg}$ & 0.47 & BeheshtiTabar et al., (2010) \\
\hline Insecticides/Pesticides/Weedicides & $\mathrm{kg}$ & 120 & Chaudhary et al., (2009) \\
\hline Insecticides/Pesticides/Weedicides & Lit. & 102 & Chaudhary et al., (2009) \\
\hline Fungicide & $\mathrm{kg}$ & 97 & Pimentel (1980) \\
\hline Machinery including self-propelled & $\mathrm{kg}$ & 68.4 & Singh and Mittal (1992) \\
\hline Animal Plough & Pair-hr & 10.1 & Singh and Mittal (1992) \\
\hline Electric motor & $\mathrm{kg}$ & 64.8 & Singh and Mittal (1992) \\
\hline Irrigation & $\mathrm{m}^{3}$ & 1.02 & Tuti et al., (2012) \\
\hline Plastic & $\mathrm{kg}$ & 90 & Canakci and Akinci (2006) \\
\hline Seeds (Rice and Wheat) & $\mathrm{kg}$ & 14.7 & Jackson et al., (2010) \\
\hline \multicolumn{4}{|l|}{ Output } \\
\hline Rice & $\mathrm{kg}$ & 14.7 & Jackson et al., (2010) \\
\hline Wheat & $\mathrm{kg}$ & 14.7 & Singh and Mittal (1992) \\
\hline Straw (wheat, rice) & $\mathrm{kg} *$ & 12.5 & Singh and Mittal (1992) \\
\hline
\end{tabular}


Table.2 Resource inputs and outputs in rice - wheat cropping system

\begin{tabular}{|c|c|c|c|}
\hline Resource inputs/ha & Unit & Rice & Wheat \\
\hline \multicolumn{4}{|l|}{ Direct } \\
\hline Labour & man hr & 802.4 & 414.6 \\
\hline Fossil fuel (Diesel) & 1 & 36.5 & 67.2 \\
\hline Electricity & $\mathrm{kWh}$ & 889.9 & 222.5 \\
\hline \multicolumn{4}{|l|}{ Indirect } \\
\hline Seed & $\mathrm{kg}$ & 24.3 & 103.3 \\
\hline Nitrogen $(\mathrm{N})$ & $\mathrm{kg}$ & 106.4 & 97.6 \\
\hline Phosphorus $\left(\mathrm{P}_{2} \mathrm{O}_{5}\right)$ & $\mathrm{kg}$ & 68.5 & 96.5 \\
\hline Potassium $\left(\mathrm{K}_{2} \mathrm{O}\right)$ & $\mathrm{kg}$ & 60.2 & 60.2 \\
\hline Farm Yard Manure & $\mathrm{kg}$ & 7500.0 & 5000.0 \\
\hline Insecticide/Weedicide & $\mathrm{kg}$ & 12.2 & 0.0 \\
\hline Fungicide & $\mathrm{kg}$ & 1.2 & 0.0 \\
\hline Machinery & $\mathrm{kg}$ & 1.4 & 1.4 \\
\hline Animal Ploughing & $\mathrm{hr}$ & - & - \\
\hline Irrigation & $\mathrm{m}^{3}$ & 6000.0 & 1500.0 \\
\hline \multicolumn{4}{|l|}{ Resource Output/ha } \\
\hline Main & $\mathrm{kg}$ & 7179 & 4710 \\
\hline Byproduct & $\mathrm{kg}$ & 7335 & 5048 \\
\hline
\end{tabular}


Table.3 Energy of Inputs and Outputs of rice - wheat system (MJ/ha)

\begin{tabular}{|c|c|c|}
\hline Particulars & Rice & Wheat \\
\hline \multicolumn{3}{|l|}{ Direct } \\
\hline Labor & 1572.8 & 812.6 \\
\hline Fossil fuel (Diesel) & 1746.02 & 3218.5 \\
\hline Electricity & 3203.9 & 801.0 \\
\hline \multicolumn{3}{|l|}{ Indirect } \\
\hline Seeds & 357.5 & 1519.1 \\
\hline Nitrogen $(\mathrm{N})$ & 6450.5 & 5914.1 \\
\hline Phosphorus $\left(\mathrm{P}_{2} \mathrm{O}_{5}\right)$ & 760.5 & 1070.9 \\
\hline Potassium $\left(\mathrm{K}_{2} \mathrm{O}\right)$ & 403.2 & 403.2 \\
\hline Farm Yard Manure & 3525 & 2350 \\
\hline Insecticide/Weedicide & 1459.0 & 0.00 \\
\hline Fungicide & 124.4 & 0.00 \\
\hline \multicolumn{3}{|l|}{ Machinery including self- } \\
\hline \multicolumn{3}{|l|}{ propelled } \\
\hline Animal Ploughing & - & - \\
\hline Irrigation & 6120 & 1530 \\
\hline Total Energy Input (MJ/ha) & 25819.4 & 17714.9 \\
\hline \multicolumn{3}{|l|}{ Energy Output (MJ/ha) } \\
\hline Energy (main) & 105531.3 & 69237.0 \\
\hline Energy (byproduct) & 91687.4 & 63099.9 \\
\hline Total Energy Output (MJ/ha) & 197218.7 & 132336.9 \\
\hline
\end{tabular}


Int.J.Curr.Microbiol.App.Sci (2017) 6(3): 1534-1544

Table.4 Energy Indices for rice - wheat system (MJ/ha)

\begin{tabular}{lcc}
\hline Indices & Rice & Wheat \\
\hline Energy Use Efficiency & 7.6 & 7.5 \\
${\text { Energy Use Efficiency } \mathrm{M}^{*}}^{\text {Net Energy(MJ/ha) }}$ & 4.1 & 3.9 \\
Net Energy $\mathrm{M}^{*}(\mathrm{MJ} / \mathrm{ha})$ & 171399.2 & 114622.0 \\
Energy Profitability(MJ/ha) & 79711.9 & 51522.1 \\
Human Energy Profitability & 6.6 & 6.5 \\
Energy Productivity (kg/MJ) & 125.4 & 162.9 \\
Direct Energy (MJ/ha) & 0.28 & 0.27 \\
Indirect Energy (MJ/ha) & 6522.7 & 4832.1 \\
Renewable Energy (MJ/ha) & 19296.8 & 12882.8 \\
Non-renewable Energy (MJ/ha) & 5097.8 & 3162.6 \\
\hline
\end{tabular}

Note: ${ }^{\mathrm{M}^{*}}$ - Main product

Table.5 Percentage of energy shared by different inputs in rice-wheat cropping system

\begin{tabular}{lcc}
\hline Particulars & Rice & Wheat \\
\hline Direct Sources & & \\
Labor & 6.1 & 4.6 \\
Fossil fuel (Diesel) & 6.8 & 18.2 \\
Electricity & 12.4 & 4.5 \\
Indirect Sources & & \\
Seed & 1.4 & 8.6 \\
Nitrogen & 25 & 33.4 \\
Phosphorus & 2.9 & 6 \\
Potassium & 13.7 & 13.3 \\
Farm Yard Manure & 1.6 & 2.3 \\
Insecticide/Weedicide & 5.7 & 0 \\
Fungicide & 0.5 & 0 \\
Machinery & 0.4 & 0.5 \\
Irrigation & 23.7 & 8.6 \\
\hline
\end{tabular}


Table.6 Econometric estimation results of direct energy, indirect energy, renewable energy, nonrenewable energy forms

\begin{tabular}{lcc}
\hline Energy input source & Coefficients & MPP \\
\hline $\ln Y i=\beta_{0}+\beta_{1} \ln (D E)+\beta_{2} \ln (I D E)+\varepsilon_{i}$ & & \\
Direct energy & 0.93 & 0.96 \\
Indirect energy & 0.29 & 0.26 \\
Constant & -2.38 & \\
$\mathrm{R}^{2}$ & 0.98 & \\
Return to scale $\left(\sum_{i=1}^{n} \beta_{i}\right)$ & 1.24 & \\
$\ln Y_{i}=\gamma_{0}+\gamma_{1} \ln (R E)+\gamma_{2} \ln (N R E)+\varepsilon_{i}$ & & \\
Renewable energy & 0.78 & 0.82 \\
Nonrenewable energy & 0.28 & 0.26 \\
Constant & -0.57 & \\
$\mathrm{R}^{2}$ & 0.98 & \\
Return to scale $\left(\sum_{i=1}^{n} \gamma_{i}\right)$ & 1.07 & \\
\hline
\end{tabular}

Fig.1 Percentage of energy consumed from different sources of energy

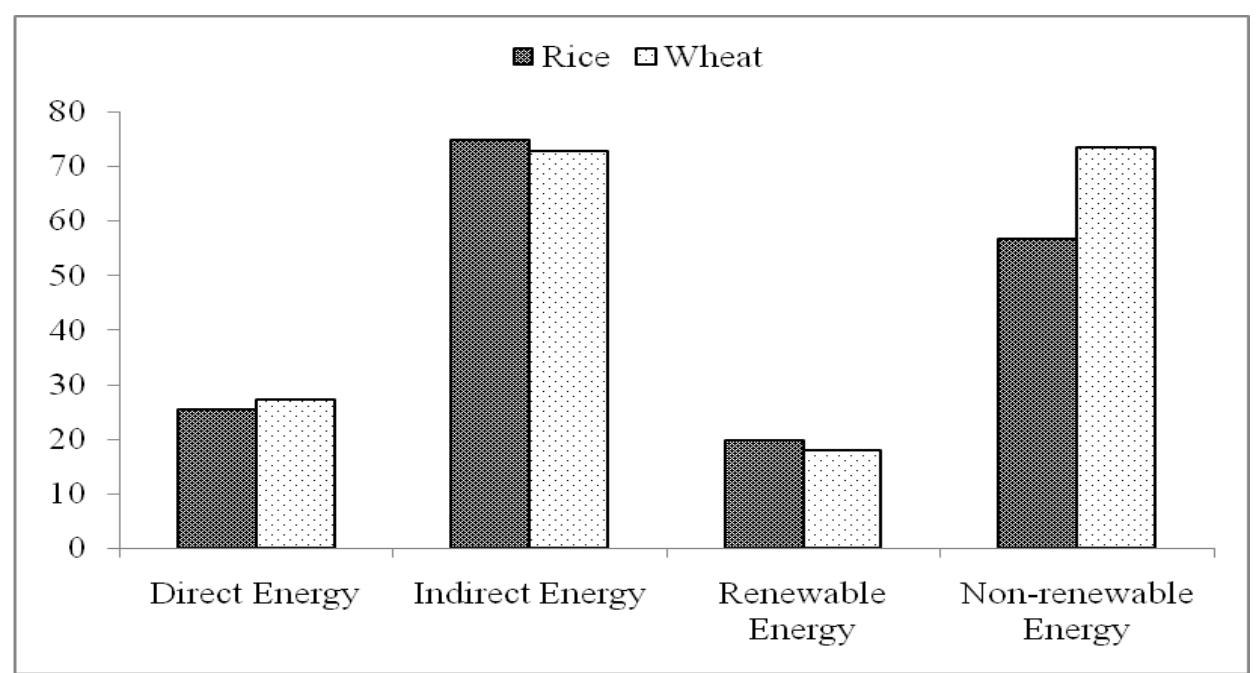

Econometric model performance of rice wheat production

The regression coefficient of DE, IDE, RE and NRE forms were found positive (Table
6). The impact of DE (0.93) and RE (0.78) was more than IDE (0.29) and NRE (0.28). The coefficients RE and NRE inputs indicate that $1 \%$ increase will lead to $0.78 \%$ and $0.28 \%$ increase in productivity, respectively. 
The result also revealed that the impact of DE (0.93) was high in enhancing rice and wheat yield. The return to scale value for model 1 and 2 were 1.24 and 1.27., respectively (Table 6) which implies increase in return to scale. The MPP values of DE, IDE, RE and NRE were $0.96,0.26,0.82$ and 0.26 , respectively (Table 6). It indicates that with increase in input of $1 \mathrm{MJ}$ energy in DE, IDE, RE and NRE would lead to an additional increase in rice and wheat yield by $0.96,0.26,0.82$ and $0.26 \mathrm{~kg} \mathrm{ha}^{-1}$, respectively. The positive MPP value of inputs indicates production will increase with increase in input. However, the present study reveals that the productivity of rice and wheat will be more with per unit increase of DE and RE as compare to IDE and NRE.

It is concluded that the energy use efficiency of crops can be quantified and stratified for optimization of energy gains in production systems. Among all energy input components in rice and wheat, synthetic fertilizers contributed more followed by fuel and irrigation water. The consumption of indirect energy source was more in both the crops showing exhaustive nature of these crops. The rice crop was more energy efficient with respect to energy use efficiency, net energy, energy productivity than wheat. However, higher human energy profitability in wheat crop indicates that wheat is more labour efficient than rice. The model indicates sensitivity towards direct and renewable energy which means with an increase in input of direct and renewable energy per unit yield of rice and wheat would increase equi proportionately.

\section{References}

Amare, D. and Endalew, W. 2016. Agricultural Mechanization: Assessment of Mechanization Impact Experiences on the Rural Population and the Implications for Ethiopian Smallholders. Engi. Appl. Sci., 1(2): 3948.

Beheshti Tabar, I., Keyhani, A. and Rafiee, S. 2010. Energy balance in Iran's agronomy (1990-2006). Renewable and Sustainable Energy Rev., 14: 849-855.

Bockari-Gevao, S.M., Wan Ishak, W.I., Azmi, Y. and Chan, C.W. 2005. Energy consumption in lowland rice-based cropping system. Songklanakarin. $J$. Sci. Technol., 27(4): 819-826.

Canakci, M. and Akinci, I. 2006. Energy use pattern analyses of greenhouse vegetable production. Energy, 31(12): 43-56.

Cervinka, V. 1980. Fuel and energy efficiency. In: Pimentel, D. (Ed.), Handbook of Energy Utilization in Agriculture. CRC Press, Boca Raton, FL, pp. 15-21.

Chaudhary, V., Gangwar, B. and Pandey, D. 2006. Auditing of Energy Use and Output of Different Cropping Systems in India. Agri. Engi. Int., 8: 1-13.

Chaudhary, V.P., Gangwar, B., Pandey, D.K. and Gangwar, K.S. 2009. Energy auditing of diversified rice-wheat cropping systems in Indo-gangetic plains. Energy, 34: 1091-1096.

Dhillon, B.S., Kataria, P. and Dhillon, P.K. 2010. National food security vis-à-vis of sustainability of agriculture in high productivity regions. Curr. Sci., 98(1): 33-36.

Erdal, G., Esengun, K. and Guduz, O. 2007. Energy use and economic analysis of sugar beet production in Tokat province of Turkey. Energy, 32: 34-41.

Esengun, K., Erdal, G, Gündüz, O. and Erdal, H. 2007. An economic analysis and energy use in stake-tomato production in Tokat province of Turkey. Renewable Energy, 32: 1873-1881.

Esengun, K., Erdal, G., Gündüz, O. and Erdal, H. 2006. An economic analysis and 
energy use in stake-tomato production in Tokat province of Turkey. Renewable Energy, 32: 1873-1881.

Gupta, R., Seth, A. 2007. A review of resource conserving technologies for sustainable management of the rice-wheat cropping system of the Indo-Gangetic Plains. Crop Protection, 26: 436-447.

Hetz, E.J. 1992. Energy utilization in Chilean agriculture. Agricultural Mechanization in Asia, Africa and Latin America 23(2): 52-56.

Jackson, T.M., Khan, S. and Hafeez, M. 2010. A comparative analysis of water application and energy consumption at the irrigated field level. Agri. Water Management, 97: 1477-1485.

Ozkana, B., Akcaoz, H. and Karadeniz, F. 2004. Energy requirement and economic analysis of citrus production in Turkey. Energy Conversion and Management, 45: 1821-30.

Pimentel, D. and Burgess, M. 1980. Energy inputs in corn production. In: Pimentel, D. (Ed.), Handbook of Energy Utilization in Agriculture. CRC Press, Boca Raton, FL, pp. 67-84.

Rutger, J.N. and Grant, W.R., 1980. Energy use in rice production. In: Pimentel, D. (Ed.), Handbook of Energy Utilization in Agriculture. CRC Press, Boca Raton, FL, pp. 93-98.

Singh, S. and Mittal, J.P. 1992. Energy in Production Agriculture. Mittal Publications, New Delhi, India.

Singh, S., Mittal, J.P. and Verma, S.R., 1997. Energy requirements for production of major crops in India. Agri. Mechanization in Asia, Africa and Latin America, 28(4): 13-17.

Soni, P., Taewichit, C. and Salokhe, V.M. 2013. Energy consumption and $\mathrm{CO}_{2}$ emissions in rainfed agricultural production systems of Northeast Thailand. Agri. Systems, 116: 25-36.

Taki, M., Ajabshirchi, Y., Mobtaker, H. G.andAbdi, R. 2012. Energy Consumption, Input-Output Relationship and Cost Analysis for Green house Productions in Esfahan Province of Iran. American $J$. Experimental Agri., 2(3): 485-501.

Tuti, M.D., Ved Prakash, B.M., Pandey, R., Bhattacharyya, D., Mahanta, J.K., Bisht, M. K., Mina, B.L., Kumar, N., Bhatt, J.C. and Srivastva, A.K. 2012. Energy budgeting of colocasia-based cropping systems in the Indian sub-Himalayas. Energy, 45: 986-993.

\section{How to cite this article:}

Paramesh, V., N. Ravisankar, Bappa Das, K. Viswanatha Reddy and Narendra Pratap Singh. 2017. Energy Budgeting and Sensitivity Analysis of Rice (Oryza sativa) - Wheat (Triticum aestivum) Cropping System in Indogangentic Plains of India. Int.J.Curr.Microbiol.App.Sci. 6(3): 1534-1544. doi: https://doi.org/10.20546/ijcmas.2017.603.176 